\title{
CONFLICT: A SYMPTOM OF TRANSFORMATION \\ OF THE COUNTRYSIDE
}

\section{OLGA DANGLOVÁ}

The paper addresses the theme of social change and transformation processes in Slovakia during socialistic and postsocialistic period, in particular an issue of reflecting changes instigated by state on macro-level by rural communities on micro-level. The author investigates antagonisms and conflicts as accompanying features of social change. She analyses social conflicts by identifying their causes, adversaries, and groups promoting different interests in two case studies based on the materials coming from field research conducted in two areas in western Slovakia. The studies bring evidence of heightening social conflicts related to the transformation of ownership relations and caused by colliding efforts to obtain control over land. The author describes various forms of the conflicts in connection to local specifics and different authorities or institutions engaged in them. She assumes that the course and variety of conflicts in Slovakia have been limited by local context, degree of durability of post-social mechanisms blurring ownership relations and users' rights as well as marginalized remnants of community models connected with traditional agrarian economy.

Keywords: social change, transformation processes, Slovak countryside, property, conflict.
Članek obravnava družbene spremembe in process transformacij na Slovaskem v obdobju socializma in po njem, še posebej zrcaljenje sprememb $z$ državne makroravni na mikroraven podeželskih skupnosti. Predmet raziskave so nasprotja in konflikti, ki spremljajo družbene spremembe. Analizirani so vzroki družbenih konfliktov in skupine, $k i$ uveljavljajo različne interese na primerih dveh studij, tj. na terenskem gradivu $z$ dveh obmocij zahodne Slovaške. Raziskavi govorita o naraščanju družbenih konfliktov, povezanih s spreminjanjem lastninskih razmerij, ki so jih povzročila nasprotujoča si prizadevanja za nadzor nad zemljo. Avtorica opiše različne oblike sporov, ki so povezani s krajevnimi posebnostmi in vpletenimi avtoritetami ali institucijam, in domneva, da sta tok in raznovrstnost teh sporov na Slovaškem odvisna od lokalnega konteksta, stopnje trajnosti postsocialističnih mehanizmov, ki zamegljujejo lastninska razmerja in pravice uporabnikov zemlje, kakor tudi od marginaliziranih ostankov skupnostnih modelov tradicionalnega kmečkega gospodarjenja.

Ključne besede: družbene spremembe, proces transformacij, slovaško podeželje, lastnina, konflikt.

\section{THEORETICAL BACKGROUND}

Theory of social conflict that puts emphasis on the role of conflict in social life came to the fore in social science in the 1950s as a reaction to the theory of Talcott Parsons whose functionalist interpretations of social relations stressed consensus and deliberately glossed over the importance of conflict in social life. Especially in the Anglo-Saxon setting, social conflict gained much attention in the atmosphere of political unrest of the 1960s. However, interest in the study of conflict is much older, esp. when we take into account the works of Machiavelli, Hobbes, Marx and Engels, who emphasized material conditions giving rise to conflict and class struggles based on ownership relations. Later conflict theorists influenced by Marxism turned their attention also to other than just purely economic interpretations of conflict. 
At the center of the theory is the thesis that social systems are the breeding grounds for encounters and struggles between individuals and groups who attempt to promote their interests. Although social conflict theorists take into account also common interests, they pointed mostly to incompatible and antagonistic interests. They strived to understand and explain different types of social conflicts through defining their sources and patterns, identification of opponents and analyzing the conflict cycle from its inception, maturation, culmination to its final stages. They tried to find both similarities and differences between different types of conflicts and in both internal and external ways of their resolution (Dahrendorf 1959; Mackintosh 1996).

Although at present the conflict theory is not considered to be a special school of thought, the initial argument that gave rise to its origins is still widely accepted. Even within the scale of "theories" explaining social change there is still a place for a theory that regards social conflict - in the form of struggle among groups promoting change and those advocating the preservation of the status quo, as the force behind social change. Other theories regard antagonisms and conflict as the cause or at least the accompanying symptom of social change. Contemporary social scientific approaches usually downplay the idea of conflict as the major cause of social change and focus more on the multiplicity of types of change. In this framework, the concept of social conflict has its stable place (Garner 1977).

\section{CONFLICT IN CONTEMPORARY ETHNOLOGICAL RESEARCH}

Ethnological research has brought ample evidence about the presence of conflict in social life. This is especially true for the research focusing on the study of processes of social transformation in Slovakia in the framework of modernization and globalization. This research took place in the years 1999 - 2005 at the Institute of Ethnology SAS under two VEGA grant schemes: "Socio-economic Trends in the Slovak Countryside" followed by the "Global Processes and Everyday Culture in Slovakia". The objective of the former was to study the rural socio-economic model from the interwar period until the present with a special emphasis given to the period after 1989. Attention was paid to the ways in which changes initiated at the macro-level of the state were reflected at the micro-level of the countryside. Empirical material has brought much evidence about the increasing social conflict stemming from opposing interests of groups and individuals. The common denominator of these conflicts was to gain control over land related to changes in land ownership and transformation of property rights. The actual manifestations of conflict varied according to the local context, and authorities and institutions involved in the conflict.

The following condensed description will sketch out two case studies based on fieldwork I conducted in two areas of Western Slovakia. The first concerns a broader micro-region in this paper called "Ostriansky", consisting of six localities, but the majority of the data comes from the village of Pálenisko. The other case study is based on data from the village 
of Kalinová. Since these concrete cases of conflict are too recent and the disclosure of real names people and institutions could be problematic, I changed the names of places, institutions as well as actors.

\section{CONFLICTUAL CHANGES OF OWNERSHIP RELATIONS - A HISTORICAL DIMENSION}

In the tumultuous periods after 1945 and 1989, the Slovak countryside was marked by discontinuous changes and escalation of conflicts related to collectivization of agriculture and, in the latter period, to its transformation. Both instances were about changes in the institution of private ownership of property - the loss and restoration of ownership rights respectively. In the former instance, individual interests were focused on gaining and retaining property which was incompatible with the officially promoted "interest of all people". It was important to exclude from the core of society those who defied this idea (Možný 1991: 53). Especially in the rural setting, the crucial right to own land reinforced by emotional ties towards multiplication of ancestral inheritance, was severely limited. Under a strong political pressure, the main losers of this conflict of existential interests were owners of larger property. People with little property and lower social status - the landless, agricultural laborers and proletarianized peasants, contributed to the escalation of the conflict (Danglová 1992: 14). The accelerating change that brought about the fall of the previously predictable, clearly structured and safe world as well as the break up of local economic models was accompanied by the disruption of the quality of social ties and weakening of social cohesion. After 1945, the macro cosmos of the state policies entered in the everyday life of country people via the bill of the Slovak National Council No. 104/45 about a speedy redistribution of land owned by Germans, Hungarians, traitors and enemies of the Slovak nation. In the Ostriansky region this bill hit particularly hard the villages of Jelce where manors with large property were particularly prominent in the local economy. On the basis of this bill the property of the family of baron Strobach was confiscated - in Jelce it was 200 ha of land, in Pálenisko, at the Nová Doba manor, it was 150 ha.

The political frame of reference of the post-war period created conditions for local communist sympathizers. Today it is difficult to judge who adopted this hard-line orientation out of conviction and for whom it was just an opportune facade to seize power in the spirit of the period rhetoric of the "rule of the people" translated into local conditions. The decisive thing was that this kind of people laid foundations of local councils as extended tentacles of the state power. Their key role was to change the life of rural people through restructuring of ownership relations by implementing the land reform.

Redistribution of land was meant to equalize social difference among villagers. ${ }^{1}$ The

1 In the countryside there were still strong negative reverberations related to the past bad experience with previous land reforms that had taken place during the first Czechoslovak republic and the war-time 
post-war reform disappointed expectations. In the first phase of the reform, the area of land reserved for redistribution was small, but equally low was people's trust in so called "peasant committees" comprised of those who were entitled to get land or who were supposed to make decisions about land confiscation and reallocation. Therefore, there was a high turnover in the composition of the committees. But in the end, their decisions caused a lot of discontent.

Many objected that committee members had selfishly abused their position and that their decisions had been influenced by intrigues, envy, immoral nepotism and interpersonal grudges when people's fate was often decided by those who were in conflict with them (Lukačka et al. 1994: 101). ${ }^{2}$

Only three years later, in 1948, the regime again intervened into fairly newly established and painfully consolidating ownership relations by issuing the new regulation No. 46/1948, which brought about the end of reallocations of manor land and its new consolidation into cooperative farms. The leading principle of the new law was the idea that land belongs to those who work on it. All land privately owned by one owner exceeding the area of 50 was to be bought out by the state. The goal was the dissolution of church property, and that of larger groupings of owners (urbár associations) as well as larger individual owners who were ostracized and labeled "kulaks" or "the village rich" (Ratica 1992). In the whole region of Ostrany, but mainly in Pálenisko where the area of land owned by the church and the urbár association was large, the law meant a radical intervention in the private ownership of property. In the village of Kalinová these pressure on the private sectors particularly struck the local winemakers and sellers.

The establishment of cooperative farms and confiscation of private property gave rise to the legally, economically and socially unlimited situation in which cooperative farms and the state farms had the right to land tenure for an unspecified time period and free of charge. Although the original property ownership was not legally cancelled, land ownership remained formally registered in the cadastre in its owners' names and was still subject to inheritance, ownership rights were severely limited. Owners could not freely use the land according to their interests and needs. This way, the previously strong felt value of land ownership was gradually declining (Danglová 2001: 287). In cooperative farms, the systems of obligations in relation to property vis-à-vis their land as well collectively utilized and managed property was weakened and even eliminated - everything belonged to everyone and none, which reinforced the system of irresponsible property management. Although the collective sector in the 1960s and 1970s underwent a transformation from simple farming

Slovak state. None of them satisfied the rural poor and small farmers whose expectations for a radical change in their social situation had not been met.

2 In Pálenisko, the highest entitlements to land allocations were claimed by former members of the resistance and guerilla fighters. According to the proposition of the local council, each of 39 applicants was to get 8 ha of land, which would mean that there would be no land left for others. Therefore, the allocation rules were redrafted several times and in the end it included 80 people. Cf. Lukačka (ed.) 1995: 72 
to modern production technologies and in the 1970s and 1980s expanded greatly thanks to generous state subsidies, the ownership dimension played virtually no role in this boom. ${ }^{3}$ According to some economists, the main cause of the failure of socialist economies lied in the interpenetration of the political and economic sphere, in the distortion and neglect of ownership rights (Barnard and Spencer, eds. 1996: 453-454). Current attempts at restructuring of socialist economies in post-socialist countries trying to draw a dividing line between the political and economic sphere and based on the market principle rather than planning, and the return to private ownership represent a unique research opportunity for ethnologists. They create space for the study of linkages between changes in ownership rights and social structure and for investigating of various strategies of adaptations of local actors to institutional transformations.

The introduction of socio-economic change in local conditions, as our research finding also attest to, was often accompanied by conflicts stemming from clashes in interests of groups and individuals. These conflicts were also fueled by mistrust that had its roots, as sketched above, in local history and past experience. Benefits of past social and economic changes initiated at the higher level but implemented in local conditions are questionable in the eyes of most local people, since most of them did not reap the benefits resulting from changes.

\section{THE LOCAL CONTEXT OF PROPERTY-RELATED CONFLICTS}

\section{TWO FACES OF DISMANTLING OF COOPERATIVE FARMS}

The model of restoration of ownership rights - be it individual or group ownership (communal or urbár associations), was introduced right after 1989 before the split of Czechoslovakia. The assumption was that socialist collective land use and property management would be transformed into cooperatives of owners and shareholders. Thus far, ensuing developments indicate that the course of this transformation project is varied. The process of interconnectedness of market economy with community-level economies is limited by the local context and ownership-related conflicts take, in the social sphere, a locally-specific shape.

For all localities of the Ostriansky region it is typical that in the course of dismantling of cooperative farms most eligible owners did not use the opportunity provided by the transformation law and did not show interest to use their own land. One of the reasons was that real opportunities to use the land in local conditions were limited by the fact that individual owners disposed of extremely low land areas. From the perspective of "survival strategies", individual owners did not have enough of motivation and incentives to claim

3 When speaking of the process forming the macro context of local changes, it is important to distinguish between the periods of early socialism (1940s-1950s), really existing socialism (1970s-1980s), restored capitalism (beginning of the 1990s) and new capitalism (2nd half of the 1990s). Cf. Ryšavý 2004 . 
their ownership rights to their land. This was coupled with long-term problems related to identification of owners, complicated and inconsistent cadastre registration (dating back to the period prior of 1945 when it used to be a common practice that owners and users of land from the same neighborhood swapped pieced of land among each other only on the basis of either an oral agreement or unregistered written agreement). After 1945, the irregularities in the registration only grew bigger. Many people moved to bigger towns, esp. from smaller, marginal localities, such as Podhorie, Naštice, Silice, which were also affected by the restrictions placed on new houses construction. Changes in land ownership, e.g. due to inheritance, were considered unimportant in the era of collective farming - therefore, people often did not register them with the authorities. New identification of owners is very complicated and costly since it can only be done on the basis of the identification of the original owners - many of whom are not alive or moved to unknown places.

The ownership of a small area of land - which is the case of most land owners in the Ostriansky region, does not provide positive incentives for a larger scale farming that would go beyond growing of produce for farmers'own consumption, as it simply would not be efficient. Therefore, people were not interested in using their land. They saw no reason to spend their time to go to the cadastre and expend their money on administrative fees to have their undervalued fragmented land areas properly registered.

The transformation of the former cooperative farm into a new cooperative association of land-owners was relatively peaceful in the Ostriansky region. The local people accepted the new cooperative as a prosperous enterprise creating jobs and yielding individual financial profits to its members - land owners.

The transformation of the socialist cooperative farm was dramatically different in the wine-growing locality of Kalinová. In this locality, due to a small overall area of agricultural land, the socialist cooperative farm, founded in 1953 to complement traditional wine-growing, reoriented its production to provison of transportation services and manufacturing of agricultural tool which employed also Roma blacksmiths. These profitable productions were closed down after the state decree issued in the 1970s mandating the merging of several smaller cooperative farms into one organizational unit when the farm in Kalinová merged with four other farms and the center of this new merged farm became the locality of Hradná. According to the former head of the Kalinová farm, it was because these productions stuck out too much to a dislike of other villages in the newly formed merged farm. Later also the animal husbandry unit was closed down and wine sales were moved to the central cellar in Hradná. To Kalinová the production of scions for grapevine cultivation was moved and new vineyards were planted on the original slopes in the extent prior to the existence of the cooperative farm. However, there was one crucial difference. While the vineyards of the original owners were situated on the hill slope in narrow vertical stripes, the cooperative vineyards disturbed this pattern and to ensure a more convenient access of machinery to the new vineyards, grapevine was planted on newly created horizontal terraces.

After 1989, when the merged farm fragmented again into the five original farms, 
problems started to mount in the Kalinová farm. The price of wine grapes went down, and it was almost impossible to sell the scions. Their production became unprofitable and it was eventually closed down. That meant that the members of the newly transformed land-owners farm were left only with unprofitable regular farming production on a small land area with little soil quality and the farm started to slip into a financial crisis.

In this bad economic situation, conflicts between the main economist and the general manager of the farm about investment and management strategies started to grow. The economist wanted to curtail investments while the manager wanted to make adequate investments to ensure new harvest. The bad situation was compounded by cumulation of other unforeseen difficulties - the overestimation of profits from wine grapes sales, a belowthe-average harvest of canola seeds, a sharp decline in the market price of wheat and the loss of $4000 \mathrm{SK}$ - which was the value of wheat given to a mill that filled for a bankruptcy. Due to the lack of finances, the farm had to stop payments to the State Treasury and there was no money left to pay wages. In 1999, the social security administration placed a distraint order on the farm's property. The members of the farm management started to blame each other for this situation. The general manager, when he saw that the farm was headed towards bankruptcy left the sinking ship with the statement that he wasn't going to let himselflock up in jail. Nowadays, as a director of a private agricultural company, he sees his experiences from cooperative farming in negative light. He claims that cooperative farming is alibism and the worst thing about cooperative ownership is that it belongs to all and none which is manifested in irresponsible attitudes towards property. Although the cooperative farm in Kalinová transformed itself into the cooperative of land-owners and its Board of Directors was formed from those who had the largest share of property, those people, e.g. elderly women, had a very limited understanding of management issues, did not take meetings seriously, engaged in petty quarrels and were unable to find constructive solutions to pressing problems. Another mistake was that the farm took on the function of a social safety net. With the land area of about 424 ha it employed as many as 45 people, which was disproportionately high. These were people shortly before the retirement age or those who couldn't find any other job. When the general manager left in 1999, his post was taken over by the former economist who now regrets this move. He saw a certain opportunity in reducing the number of employees. This move angered the regular members of the farm. Although the Board of Directors agreed with the decision of the new general manager they could not agree on who and how many people should be laid off. In the end they chose the "lesser evil" and did not lay off anybody. Even the attempt to sell an unused warehouse failed. They could not sell it due to unsettled ownership issues related to the plot on which it was built. Also attempts to raise funds through a fusion with an external investor failed. In the end, all property of the farm was bought by the construction company Agriko a.s., the director of which was the former general manager of the old collective farm.

When the cooperative filed for bankruptcy, land shares were returned to the owners. However, this was done without proper identification of their location and without proper 
demarcation of acreage. The Agriko company put forth a proposal to either buy the land from its owners or rent it for the period of 30 (vineyards) or 15 years (arable land). The company's argument to explain these conditions was that they had to defend their own investments, which were, for instance, into grapevine about 1 million SK per 1 ha of land, when it takes about 4 years for the vineyard to start yielding grapes. The proposed long-term rental of land antagonized the land owners against the company, and this sentiment was further reinforced by the fact that the company requested the title to the land ownership, which for the people incurred additional administrative costs. Therefore, in case of the vineyards the situation is such that the owners are not willing to sell their land due to the low price neither are they willing to rent it out given the proposed conditions. Agriko a.s. owns about 120.000 grapevine plants but they have no land. On the contrary, the owners do have land but the grapevine, planted by the former farm, is not their. The situation is similar when it comes to the land on which technical buildings stand.

There would be ways to resolve this deadlock situation - either to dissolve the terrace, recreate the original, difficult to farm, stripes of vineyards, and undertake a yet another redistribution of the land or to sell all vineyards to one owner.

To sum up - during socialism in the Kalinová farm the source of social conflict were differentiated efforts to organize the farm's economy or the economy of the merged farms when politically stronger groups and influential individuals took decisions about the nature of production, investments into construction, purchase of machinery and capital investments. These people wielded political power to pursue their interest and goals and they often manipulated people into a disadvantageous position. Everything was based on the principle of dependence.

After 1989, confrontational and confusing stances of those in decision-making positions and the representatives of the farm's management towards the transformational processes within the farms led to its dissolution and the creation of a new joint-stock company. Besides agricultural land, the owners lost also their property shares from machinery and technical buildings. The source of conflict and impulse for its escalation were mainly the unresolved and unclear issues around land ownership.

\section{CONFLICTS AROUND CONSTRUCTION PLOTS}

While the efforts for the settlement or restitution of ownership rights to agricultural land where either rather insignificant (in Ostriansky region) or chaotic and confusing (in Kalinovo), people were much more interested in getting a clearance of small construction plots and gardens situated within the inner boundaries of the village. This interest was pragmatic - in the given situation construction plots could yield more secure and higher profits.

\section{At the level of the locality}

The problem with identification of ownership concerns also village mayors. The mayor of 
Silice complained about problems with the main village road - one part of it is owned by the Slovak Road Administration (Slovenská správa ciest), a part of it belongs to the village and the rest is owned by about 40-50 people. The local government does not have enough financial means to clear ownership records. The mayor argues that in this situation, when the village is not the owner, the road maintenance is actually being done unlawfully. The enormous fragmentation of ownership is often the obstacle of efficient utilization of land also from the perspective of public interest - due to unsettled ownership and unwillingness of one owner of a plot of the area of $40 \mathrm{~m}^{2}$, Silice cannot apply for a subsidy for infrastructure development.

\section{Within the family}

In some case, conflicts around ownership also affect family relations. In Zanadlúčie there was an inheritance case in which an original construction plot was divided into four narrow strips of land among four family members. This new division rendered the plot useless for construction purposes. The only solution would be if at least one of the heirs sold his part to the others. Each pursued their own interests and none wanted to give up their part. This upset the family solidarity and its unity was shattered because of financial calculations.

\section{In coexistence of neighbours}

In Naštice, the source of conflicts among neighbours is common yards. Conflicts erupt especially in cases of unclear property transfers and divisions when in the past inheritance rights to the houses were not cleared and ownership certificates are missing. This is often

the case of old houses. Neighbours quarrel because of access to the road, noise or the way of utilization of the yard. In case when the yard is inhabited by both the local people and weekenders, conflicts stem from discrepancies in different life-styles and views about utilization of yards.

In the Ostriansky region in Pálenisko, local people are mostly interested in the transfer of plots surrounding the dam Lipianka. The price of the plots is high due to the fact that they are located in a recreational area. It should be said that it concerns pastures and forest areas that mostly belong to the renewed Association of Land Users (urbárske spoločenstvo).

\section{THE RESTITUTED ASSOCIATION OF LAND USERS (URBÁRSKE SPOLOČENSTVO)}

Urbár, a form of land registry and management, which has its roots in feudalism, represented, in the form of urbár associations, a model of communal ownership - peasants could inherit the right to use the land registered under urbár according to land shares given by the area of the estate. Since 1871, based on the act issued by the Hungarian parliament, also forests and pastures fell under the communal ownership of urbár associations (Encyklopédia 
Slovenska VI: 192-193). In Pálenisko, similarly to other parts of Slovakia, the members of the association collectively took care of the forest. In addition to fuel and construction wood, the forest yielded also oak bark used as a coloring agent. Urbár associations were abolished after 1945, and forests and pastures that formally stayed in their ownership were nationalized by the state.

While studying the trajectory of restoration of pre-socialist ownership in Pálenisko, I came across the escalation of an economically motivated conflict. A protracted argument about unsettled restitutions of forests and pastures of the former Urbár Association is an example of the lack of trust not only to the newly revitalized institution of the Urbár Association but also its general lack among the local people themselves. The specificity of the case lies in the fact that the nexus of the conflict - that has been dragging on since 1991 - 1992, are attractive plots in the recreational area around the dam. The conflict that ended up before the court of law, started from initial collisions about ownership and management of the property of the Urbár Association. It involved the members of the Urbár Association, people who allegedly illegitimately got into its managements, the local administration, owners of chalets and employees of the State Forests Adminstration. This conflict tells us much about the quality of social relations and of the lack of trust at different levels - among organizations, inside the Urbár Association as a renewed organizational form, and among individual people in everyday interpersonal relations. What were the sources of the conflict, in which way the opposing parties defined each other, what were their goals and what means did they use? I tried to follow these questions through a method that could be termed "investigative ethnography".

I based my search for the circumstances surrounding the Urbár Association and for the reconstruction of the whole case on narrative interviews. My respondents were the key actors with different strategic positions in the conflict. I confronted their narrations with data from other informants. I am aware of the fact that the only way I can present the collected data is how I heard and recorded them. I am also aware of the limitations of this method. Due to situational limits, lack of time and sensitivity of the whole case I could not adequately confront the collected testimonies with ther real conduct of actors. Nonetheless, I used them with a sincere effort to penetrate into the unfinished story of the Urbár Association in Pálenisko.

\section{KEY ACTORS OF THE CONFLICT}

In the period of revitalization of the Urbár Association, the conflictual rather than cooperative relations were the most prominent. These were aimed inside the Association but they could also be observed between the Association and other organizations or individuals operating within the sphere of land ownership and utilization (the Local Office, Forest Administration, owners of chalets, entrepreneurs). Using the case study method, I tried to penetrate to the basis of the conflict by collecting the opinions of the actors of the conflict - individuals, institutions and groups pursuing their own interests. In the following 
I present abridged transcripts of their strategic stances and views from the perspective of their position in the conflict. The way I interpret them is compatible with the context of actions of the concrete individuals, institutions or groups. Therefore, there can be a number of relevant understandings of social reality.

Although the Forest Administration Lipianka as an organization is not directly involved in the conflict, from its point of view and its interpretation of the situation it is clear that it stresses its own interests. At present, they manage about 3500 ha of forest, out of which 1413 ha is in the village of Pálenisko, 2083 ha belongs to Podhorie, 157 ha to Naštice, the rest is divided between two other neighboring localities. In 1990, from its forest acreage the Forest Administration handed to the Urbár Association and private entrepreneurs116 ha in Pálenisko, 168 ha in Podhorie, 72 ha in Naštice. An opinion of an employee of the Forest Administration about the establishment of the Urbar Associations:

As concerns the forest, the state constantly changes its regulations under the assumption that the forest will endure everything. Well, and the Urbar Associations, that's these granddads who thought that when they got the forest back they will take care of it. But they were lacking expert knowledge. We pointed out to them that without means of production and employees they wouldn't be able to follow the production plan, and is not profitable to manage 100 ha of forest, but they didn't listen. But forests produce no gain all over Europe, the forest needs investments. They were telling us that for forty years we, as communists, had been steeling wood here. Now we handed it over to them and they don't do anything and experts don't want to do it for them. Employment offices offer them people but an unemployed asocial can't do everything in the forest. It's rather difficult when it come to, say, chain saws, one costs about 30.000 Sk and only those who have a certificate about a 2-week course can work with it. This rules out $90 \%$ of applicants. It's easier to hire people from the employment office to plant trees - that doesn't require a special qualification.

After they took over the forest, the first thing the members of the Urbar association wanted to do was, of course, to start logging. Some were fined for illegal logging and later they needed to find someone to do that and sell the wood as well. They found two people but both swindled them.

The State Forest Administration Lipianka delivers wood to the transportation-manipulation administration in Ostrany. They then sort it and manage sales, they also sell to small buyers. Overall, however, compared to the past, the volume of forestry works has gone down, there isn't as much money as it used to.

All forests are also hunting places. These are either managed by the State Forests or the State Forests rent them out to local hunting societies. There is 
a hunting society here in the village that takes care of wild game; they only pay rent to the State Forests. (Employee of the Forest Administration)

A member of the Board of the Urbár Association and its new head, elected in 2001, illustrates the key position that institutional authorities take in the conflict. From their perspective the situation looks as follows:

The application for the restitution of the Urba'r Association's property was submitted in 1991-1992. It was submitted by teacher Pekár, who was later regularly elected the head of the Association. After him (here the local mayor gets involved in the conflict) the mayor placed Pekár's daughter Zelenková, who does not have a share in the Association, in a position on the Board and she got to the post by an election fraud. She got together with entrepreneur Solc. Until 200, they both kept all documents of the Associations, called off the treasurer and usurped the treasury when the new head was elected.

The figure of R. Šlc has a special place in the conflict around the Association's property. The Association's members suspect that he illicitly bought the rubber stamp of the Association and used it to forge various official operations although he had never been elected a Board member:

He cut down timber in the urbár forest and sold it to an unknown customer and took the money. He claims it was a low quality wood that he didn't make any profit on and therefore the Association didn't gain anything from that transaction. But he didn't submit any documentation. They took the wood away in secret, it was more than 100 quadratic meters, he certainly made a lot on it but he didn't give anything to the Association. None of the members had ever given him any permission for logging but from individual members they both with Zelenková got powers of attorney to act on their behalf. The Association members sued him but the district attorney rejected the case, of course, because Šolc has his people at the court. When the hearings were getting to the end, Šlc popped in the court room and the case was adjourned.

Entrepreneur Šolc. Who is entrepreneur Šolc about whom one of the Association members said that

he is a rat who started out by transporting and selling alcohol in trucks and now he is a big moneybags. He doesnt have any education but that didnt prevent him from getting involved in politics after 1989 and from campaigning for one party and its prominent representative.

His former employee described him as good at business but without a backbone.

R. Šolc got into private business in the early period of restoration of capitalism at the beginning of 1990s. From the very beginning in his business intentions he tried to reach beyond the local microcosm and enter a larger supra-local space. The sale of urbár wood 
was just an interlude in his business career. ${ }^{4}$ This is how Šolc comments on the situation around the urbár land:

The urbár books were saved by teacher Pekár. He was a precious person, I learned a lot form him. He was present at the founding of the Urbar Association but, and here he fabricates events, he paid for it with his own life, they killed him. Pekár gave me all papers concerning the Association, I still have them. People who are involved in law suits come to me to get advice.

In his interpretation of the case with sales of wood he sticks to his version about the low quality wood.

The case of the underhand sale of wood is not the only aspect of the conflict within the Urbár Association. Another point at issue is property shares. It is true that the number of shareholders can change from one year to another due to inheritance, but the differing numbers of shareholders I got from other sources are suspicious. One Board member, who disposed of the association's documents in an interim period after the previous Board, said the number of shareholders was 315 in 2000 but in 2001, according to the list of the new Board chairperson, the number went down to 237. The Local Office recorded 500 shareholders, most likely on the basis of inheritance certificates. The Board chairperson claimed that the Local Office had nothing to do with the number of shareholders and the

4 An elderly women - owner of a chalet at Lipianka, joined in the negative characteristics of R. Šolc. She evaluated with suspicion his business activities and his expansiveness: He's a DJ who made money on playing music and now he has two or three chalets here at the dam, he also has two houses too and is incredibly cocky.

According to her, this is what Šolc's business career curriculum vitae looks like: After 198, I bought a shoe and garment warehouse building in Pálenisko and converted it into a store with the same goods. But people didn't have money and the goods weren't selling well, so I closed the store down. In addition to tha,t I was running eight businesses in the recreational area Lipianka, three of them - a café, discotheque and video café were owned by the Local Office. In the summer season I employed 72 people. When I remodeled the business, right after the reconstruction the Local Office took it away from me. Through a tangle of communist connections, in which the Local Office featured too, the business gained fradulent loans from the management of the Slovak Savings Bank and the owners, convicted in the court of law, sold the business illegall without our knowledge. Therefore we were forced to stop our activity in the whole valley and temporary close our businesses. When they closed down hotel Lipianka I was told: "Stop, or they will kill you!" So we switched to other activities. We took up arts.

In Pálenisko, Šolc built a digital recording studio equipped with the most up-to-date technology. He organizes artistic events and concerts both in Slovakia and abroad: We do it all-- from producing master recordings to promotion and advertising to production of CDs and graphic design. I have my own sound and light system, transportation, we can build a stage and cooperate with the media both here and abroad. This is the only thing they allow us to do in the EU countries.

I build my own network of collaborators. But during concerts I don't employ the local people thought their moms or the confessional. Here in Pálenisko, I have a recording studio, service, club and administration. When a crew comes, they record what the need. In addition to that we provide them with a film and press materials. I.e. we advertise our products so that we can sell them for prices they give us. It's a sort of a game. Right now we're recoding the Nabucco CD. If you can wait a while $M s$ [he gives a name of a famous opera singer] will turn up. 
creation of their list was exclusively in the competency of the Association's members. This is correct, but in the background of this game with numbers is also the interest of those already registered not to expand the number of shareholders as that would proportionally diminished their shares.

Difficulties with consolidations of relationships within the Association, problems with the creation of the basis of institutional trust, a lack of trust in the Board, and suspicions among the Board members themselves continued also in 2003 and culminated in a conflict between the Board chairperson and the treasurer concerning the competency to dispose of the Association's finances. The chairperson got accused that she had allocated financial bonuses to those Board members who were on her side. But financial bonuses can only be paid upon the officially endorsement by the general assembly of all members. At a general meeting, this conflict manifested itself through mutual accusations and culminated in the quarrel that also got transferred into the plenary. People would perhaps shoot each other there, with these words one of the shareholders present at the meeting commented on its course.

The Mayor of Pálenisko defends his position in the conflict by observing institutional rules. According to the Association's members, land and chalets owners, from the position of the local authority representing the village he also promotes his own interests. He represents continuity with the former socialist local National Committee (národný výbor). He took over the position of Chair of the National Committee in 1988, he was able to hold on to it and defend it also in the elections in 2003. Thanks to his long-term activity on the local scene, he accumulated a lot of social capital, gained good knowledge of the local and regional setting, which guaranteed him a better bargaining position also vis-à-vis the Association's members. He defends himself against attracts from the Association by arguing that land documentation was approved by the Local Council, publically posted and everybody could look into it. In turn, the owners of land argue that the Local Office expropriates anybody with witnesses. They claim it was posted at the Office. When one argues against it they find witnesses.

The Local Office indeed exerted much efforts to carry out uneasy documentation of land ownership that was rather complicated due to the documentation disorder and lack of clarity inherited from the past - in socialism, the state owned everything, therefore the exact ownership documentation was neglected or incomplete and often the ownership titles to the land were missing.

Šlc, this time in concert with the members of the Urbár Association and some chalets owners, characterizes the controversial relationship between the Local Office and the Association as follows:

Forest parts were given back on the legal basis, but the situation was worse with pastures that during socialism, the Local Office registered as its property. When the dam Lipianka was being built they forcibly expropriated pastures belonging to the Urbarr. The office paid us peanuts and now they are selling the land for a high price. The mayor sells land, belonging to concrete people, to his chosen ones and when he issues to someone a construction 
permit to build a chalet he pockets cash money. The auto camp and the whole recreational area of Lipianka are built on the land of our grandfathers and great grandfathers.

(Here for the first time - although perhaps just in the form a proclamation, appears an argument stressing not individual or group benefits but rather the emotional dimension of the value of land as the "family heritage", communal identity).

The source of the clash between the Local Office and the members of the Association was a clashing demarcation of plots borders and related ownership claims. ${ }^{5}$ The conflict ended up in court and was temporarily adjourned due to a formal mistake - the Association should have sued the village not the Local Office.

Another object of communal conflict was hotel Lipianka, located in an attractive setting of the dam. This hotel with a large capacity, in the summer season serving as many as 1200 meals a day, was until 1989 owned by the state cooperative company Jednota. At the end of 1980s, it was remodeled and the local people highly rated its quality at that time. At the beginning of the 1990s, it became the object of privatization efforts of several parties. Among the interested were the village and entrepreneur Šolc, for whom Zelenková approved the lease of the urbar plot on which the hotel was built. In the hotel, Šolc was running a video café with the intention of buying the whole hotel. According to the Mayor:

In the end the hotel was sold to the firm Coloni who gave a bribe of one million. The firm got a good bank loan and right away they sold the hotel to another company $Q$, who again got a loan from the Slovak Savings Bank against the value of the hotel. This way the company made 17,5 millions and before long the closed the hotel down. The hotel fell victim to a gradual pilfering. Then the village filed a complaint with the ministry that the Slovak Savings Bank did not protect its property. In the meantime, somebody burned the hotel down. At present they filed for bankruptcy and it is administered by the County Court. All documentation got lost and one of the managers was murdered.

People spread rumors that the hotel was set on fire by Šolc, who had a high insurance on the equipment on the video café and before starting the fire he had moved the equipment out. ${ }^{6}$ At present, the ruin of the burned hotel, located in the most attractive site with the most sunlight and the best grassy beach, became a negative attraction of the recreational area. Tourists sometimes stop there and exchange information and conjectures about arsonists and thieves, and tell stories about the burned-down hotel.

The restoration of the Urbár Association, which during the restitution process gained

5 According to the conviction of the Association's chairperson: The Mayor had illegally registered five plots of land in his name; according to other unofficial versions: he sold the urbár plots to twelve doctors (a member of the Association); he sold fifty urbár plots for chalets construction (a chalet owner at Lipianka).

6 An elementary school teacher who taught Šolc in school defends him: I don't think he's an arsonist. I don't think he would go that far because of money. 
its legal status and identity, takes place officially at the level of the state economic transformation but, simultaneously, it is also taking shape unofficially through the efforts of various subjects who, according to their ideas, want to get a registration of their right to property to which they claim their alleged ownership (Možný 1991). The high turnover at the postions of power within the subject reveals weaknesses in the organization and its management. According to Jiři Kabele, the final transfiguration of the subject can take place either in the institutional regime through a general observance of the order decreed from the top or through its using and abusing. It can have a regular or deviant dimension (Kabele 2004: 234). In the provisional nature of the present and unclear contours of the world of stories, in the case of the Urbár Association in Pálenisko the latter alternative prevails. In an instable and unbalanced social setting, it is difficult to estimate its direction and future prospects.

\section{CONCLUSIONS}

The advantage of case studies used in my account is that their record of concrete cases, analysis of real events and their authenticity enable a deeper, almost laboratory, penetration into social reality. On the other hand, their disadvantage is that they are inadequate in explaining the general pattern - in our case a broader model of social change and related situations of conflict. Nevertheless, since my argumentation is based also on the field data from my previous research of transformation processes in the rural setting, I argue that my ethnographic records illustrate broader and more general aspects explaining conflictual moments accompanying the course of social transformation.

Communal clashes and interpersonal struggles are accompanying features of economic restructuring promoting the return to the pre-socialist ownership model, esp. in terms of land ownership, and its transfer from the macro-level to the micro-level of the post-socialist village. Sources of conflict lay in differing individual and group claims to ownership, utilization and control of land; not any land but the land that represents a potential source of capital and ensuing profit. The model of transformation did not envision implications stemming from unclear ownership rights in Slovakia and from enormous fragmentation of ownership that still grows worse due to inheritance. This inconsistency in the concept of the universal model of market economy often forms the background of tensions and conflicts at the micro-level of the community. It appears that most actors of changes did have basic knowledge of the rules of the game stipulated by the law as to how to claim their rights. However, the bounds of the playfield and limits of the rules for claiming rights were not

solid and clear enough. This led to conflicting and contested interpretation of the rules, and to shady counter-strikes accompanied by mistakes and scams on all opposing sides. The truth was always on the side of the narrator of the story about the causes and course of the conflict. The most common leitmotif of the stories was either rightful claims, or 
accusation of false claims, to gain control over the land that, in the given situation, had a high market value. ${ }^{\text {? }}$

It should be said that the course and variability of conflict, the underlying motive of which is to gain control of land, is in the Slovak village still limited by the local context, the degree of durability of post-socialist mechanisms bluring the ownership and users' rights but also by marginalized remnants of communal models of the peasant economy.

\section{REFERENCES}

Barnard, Alen and Jonathan Spencer (eds.)

1996 Encyclopedia of Social and Cultural Anthropology London and New York: Routledge.

Barth, Frederik

1997 Economy, agency and ordinary lives. Social Anthropology 5: 233-242.

Buchowski, Michal

2001 Rethinking Transformation. An Anthropological Perspective of Postsocialism. Poznań: Wydavnictwo fundacji Homaniora.

Dahrendorf, Ralf

1959 Class and Class Conflict in Industrial Society. Stanford, CA: Stanford University Press

Dalton, George

1971 Economic Anthropology and Development. Essay on Tribal and Peasant Economics. New York: Basic Books.

Danglová, Ol'ga

1992 Modernizácia a demodernizácia rol'níckej ekonomiky [Modernization and Demodernization of the Peasant Economy]. In: Zmeny hodnotových systémov v kontexte každodennej kultúry. Výsledky výskumov v roku 1992 [Changes in Value Systems in the Context of Everyday Culture. Findings of Research in 1992]. Bratislava: Ústav etnológie SAV.

1995 Rural Communities in the Process of Socio-Economic Change. Collegium Anthropologicum [Zagreb] 19: $129-144$.

2001 Rurálna komunita v transformácii [The Rural Community in Transformation]. Slovenskýnárodopis 49 (3): 279-299.

2006 Slovenský vidiek. Bariéry a perspektivy rozvoja [Slovak Countryside. Barriers and Perspectives of Development]. Bratislava: Ústav etnológie SAV.

Danglová, Ol'ga et al.

2005 Vidiekvprocese transformácie. Výsledky výskumu jedného západoslovenského regiónu [Countryside in the Process of Transformation. Outcomes of a Research in a Western Slovakian Region]. Bratislava: Zing Print.

7 Jiří Kabele characterizes a so called narrative dimension of power, which means that narration delineates the mutual relationship of peoples and defines the implications of the game, defines the distribution of merits and responsibilities. The power game is not as much about by rivalry or struggle at the level of behavior as it is about the struggle at the level of rhetoric (Kabele 1998: 180). Examples of the narrative dimension of power used in their analysis of agricultural entrepreneurs in South Moravian border regions present also Helena Hudečková and Michal Lošták (2004). 
Encyklopédia Slovenska

1982 Encyklopédia Slovenska [Encyclopedia of Slovakia]. VI. zväzok. Bratislava: Veda.

Filipov I.

1998 Praha. Praha: Informatoria Katerdry sociologie Fakulty sociálních věd University Karlovy v Praze. 1999 Praha. Praha: Informatoria Katerdry sociologie Fakulty sociálních věd University Karlovy v Praze.

Garner, John

1977 Social Change. Chicago: Rand Mc Nally College Publ. Comp.

Halamska, Maria

1996 Proces privatizace v Polsku. Konflikt nebo consensus [The Process of Privatization in Poland. Conflict or Consensus]. In: Pưvodni a novi vlastnici. Strategie nabýváni majetku ve stréedni a východni Evropě [Original and New Owners. Strategies of Property Acquisition in Central and Eastern Europe]. Praha, 239-260.

Hann, Christopher M.

1993 From Production to Property. Decollectivization and Family-Land Relationship in Contemporary Hungary. Man. The Journal of the Royal Anthropological Institute of Great Britain and Ireland 28: 299-319.

1995 The Skeleton at the Feasts. Contributions to East European Anthropology. Centre for Social Anthropology and Computing University of Kent at Canterbury.

Haukanes, Haldis

2004 Velká dramata - obyčejné životy. Postkomunistické zkušenosti českého venkova [Great Dramas - Common Lives. Postcommunist Experience in Czech Countryside]. Praha: Sociologické nakladatelství.

Hudečková, Helena and Michal Lošták

2004 Jedna lokalita, dva zemědělské podniky. Jeden nebo dva světy? [One Locality, Two Agricultural Businesses. One or Two Worlds?]. In: Kandert (ed.) 2004, 137-161.

Kabele, Jiř́

1998 Přerody. Principy sociálniho konstruováni [Transformations. The Principles of Social Construction]. Praha: Karolineum.

2004 Přerodové procesy ve Filipově a v české společnosti [Transformation Processes in Filipov and in the Czech Society]. In: Kandert (ed.) 2003, 23-40.

Kandert, Jozef (ed.)

2004 Jihomoravský venkov po socializmu [Moravian Countryside after Socialism]. Praha: Univerzita Karlova v Praze Fakulta sociálních věd.

Krivý, Vladimír

1993 Sociokultúrne pozadie problémov transformácie na Slovensku. Sociológia 25 (4-5): 311-326.

Lukačka, Ján (ed.)

1995 Obec Jacovce 1245-1995. Bratislava: Minor.

Lukačka, Ján et al.

1994 Prašice 1224-1994. Bratislava: PEN STYLE. 
Mackintosh, N. J.

1996 Conflict, social. In: Kuper, A. and. J. Kuper (eds.), The Social Science Encyclopedia. London and New York: Routledge, 122-125.

Možný, Ivo

1991 Proč tak snadno? [Why so easily] Praha: Slon.

Ratica, Dušan

1992 „Kulaci“ a proces združstevnenia na slovenskej dedine ["Kulaks” and the Process of Formation of Cooperative Farms in the Slovak village]. In: Zmeny v hodnotových systémoch v kontexte každodennej kultury. Výsledky výskumov v roku 1992 [Changes in Value Systems in the Context of Everyday Culture. Findings of Research in 1992]. Bratislava: Ústav etnológie SAV, 24-31.

Ryšavý, D.

2004 Filipovský průmysl a podnikání v obchodě a ve službách [Industry and Entrepreneurship in Trade and Services]. In: Kandert (ed.) 2004, 117-135.

Steward, Michael

1998 "We should build a Statue to Ceaucescu here." The Trauma of De-collectivization in two Romanian Villages. In: Bridger, S. and S. Pine (eds.), Surviving Postsocialism. Local Strategies and Regional Responses in Eastern Europe and Former Soviet Union. London.

Szelényi, Ivan

1988 Enterpreneurs. Enbourgeoisment in Rural Hungary. The University of Wisconsin Press.

Verdery, Katherine

1994 The Elasticity of Land. Problems of Property Restitution in Transylvania. Slavic Review 53 (4): 1071-1109.

\section{KONFLIKT. SIMPTOM TRANSFORMACIJ NA PODEŽELJU}

Članek obravnava družbene spremembe in procese transformacije v socialističnem in posocialističnem obdobju, še posebej zrcaljenje sprememb z državne makroravni na mikroraven podeželskih skupnosti. Avtorica raziskuje nasprotja in spore kot spremljajoče značilnosti družbenih sprememb. Družbene konflikte anlizira na primeru terenskega gradiva dveh študij na zahodnem Slovaškem z ugotavljanjem njihovih vzrokov, tekmecev in skupin, ki uveljavljalo različne interese.

Po prelomih leta 1945 in 1989 je bilo slovaško podeželje podvrženo diskontinuitetnim spremembam in rastočim konfliktom, povezanih s kolektivizacijo, $v$ zadnjem času pa preoblikovanju kmetijstva. Oboje je poseglo v institut zasebne lastnine: z zaplembami in potem vračanjem.

Ustanavljanje zadrug in zaplembe zasebne lastnine so ustvarile razmere, $v$ katerih zadruge in državne posesti niso omejevali pravni, ekonomski ali socialni predpisi in so lahko uporabljale zemljo za nedoločen čas, ne da bi jim bilo treba za to plačati. Čeprav prvotna lastnina pravno ni bila zbrisana in je še bila predmet dedovanja, so bile lastninske pravice strogo omejene. Lastniki niso mogli prosto uporabljati zemlje po svojih interesih in potrebah in so sčasoma zgubili interes za obdelovanje in izrabo zemlje kakor tudi lastninski čut. Oslabele so obveznosti, povezane z lastnistvom in zemljo ter kolektivno uporabljeno in upravljano posestjo, kar je krepilo neodgovorno 
upravljanje lastnine. Čeprav se je zadružništvo v 60. in 70. letih prejšnjega stoletja iz preprostega kmetovanja spremenilo s sodobno kmetijsko tehnologijo in $v 70$. in 80. letih pomembno razširilo zaradi radodarne državne pomoči, lastništvo pri tem razcvetu ni imelo nikakršnega pomena. Do obnove lastninskih pravic - individualnih ali skupinskih (skupnostna ali urbarska združenja) je prišlo takoj po letu 1989, pred razpadom Češkoslovaške. Zamisel je bila, da bi se socialistična kolektivna raba zemlje in upravljanje lastnine preoblikovali v zadruge lastnikov in delničarjev. Razvoj, ki je sledil, je pokazal, da smer tega preoblikovanja ni bila jasna. Vez med tržnim gospodarstvom in gospodarstvom na ravni skupnosti je precej omejeval lokalni kontekst. Tako so spori izvirali iz vprašanj lastništva in lastnine in so imeli v lokalnih razmerah specifične oblike. $V$ članku sta predstavljeni študiji primerov, ki opisujeta proces dekolektivizacije na nekdanjih zadružnih posestih. V prvem primeru je bilo preoblikovanje $v$ zadruge delničarjev relativno mirno. Zadrugo so krajani doživljali kot uspešno podjetje, ki ponuja zaposlitve in zagotavlja ugodnosti delničarjem, ki so lastniki zemlje v obliki zakupa. V drugem primeru so bojeviti in protislovni odnosi oblasti in upravljavcev zadružnih posesti do preoblikovanja vodili $k$ njihovi likvidaciji in ustanovitvi delniške zavarovalne družbe. Tako so ljudje zgubili pravico, da bi uporabljali zemljo, prav tako pa svoje delnice. Spor se je stopnjeval predvsem zaradi neurejenih in nejasnih lastninskih razmerij.

$V$ nadaljevanju so predstavljeni napori, da bi razjasnili in obnovili lastninske pravice in pravila upravljanja kmetijske in zazidalne zemlje. S tem povezani spori so nastali v krajevnih skupnostih in so se izražali $v$ družinskih in medsosedskih odnosih. Avtorica je posebej pozorna na spore $v$ zvezi z obnovitvijo urbarskih združenj, ki predstavljajo poseben način upravljanja z zemljo in občinsko lastnino s koreninami v fevdalni dobi.

Gospodarsko prestrukturiranje, ki spodbuja obnovo predsocialističnih lastninskih oblik, zlasti lastnino zemlje, so pogosto spremljali prepiri v skupnosti in medosebni spori. Ti so bili nasledek različnih zahtev posameznikv in skupin $v$ zvezi z lastništvom in upravljanjem zemlje. Na Slovaškem projekt preoblikovanja dejansko ni upošteval nedoločnih lastniskih razmerij in obsežnega razpada lastništva, ki ga je krepilo dedovanje. Takšno neskladje v splošnem modelu, ki je zagovarjal tržno gospodarstvo, je bilo navadno okvir za napetosti in spore na lokalni mikroravni. Zdi se, da je večina udeleženih v osnovi poznala pravno določena pravila igre, ki so določala, kako lahko terjajo svoje pravice. Vendar meje igrišca in omejitve pravil niso bile dovolj ostre in jasne. To je omogočilo, da so akterji in ustanove konfliktno interpretirali pravila in da je prihajalo do nepoštenih udarcev, ki so jih spremljale napake in goljufije na vseh straneh. Resnica je bila vedno na strani pripovedovalca zgodbe o vzrokih in poteku konflikta.

Na slovaškem podeželju sta bila potek in raznovrstnost sporov, povezanih z nadzorom nad zemljo, odvisna od lokalnega konteksta, stopnje vztrajnosti postsocialističnih mehanizmov, ki so zamegljevali pravice lastnikov in uporabnikov, pa tudi od ostankov skupnostnih modelov kmečkega gospodarjenja.

Dr. Ol'ga Danglová, Institute of Ethnology SAV, Klemensova 19, 83164 Bratislava, Slovakia, olga.danglova@savba.sk 